\title{
Hydrogen Peroxide Sensors for Biomedical Applications
}

\author{
Jakob Meier, Eric M Hofferber, Joseph A Stapleton and Nicole M Iverson * \\ Department of Biological Systems Engineering, University of Nebraska Lincoln, 251 Chase Hall, Lincoln, \\ NE 68583, USA; Jakob.Meier@huskers.unl.edu (J.M.); Eric.Hofferber@huskers.unl.edu (E.M.H.); \\ Joseph.Stapleton@huskers.unl.edu (J.A.S.) \\ * Correspondence: Iverson@unl.edu; Tel.: +1-402-472-0884
}

Received: 3 November 2019; Accepted: 26 November 2019; Published: 6 December 2019

\begin{abstract}
Hydrogen peroxide $\left(\mathrm{H}_{2} \mathrm{O}_{2}\right)$ is an important molecule within the human body, but many of its roles in physiology and pathophysiology are not well understood. To better understand the importance of $\mathrm{H}_{2} \mathrm{O}_{2}$ in biological systems, it is essential that researchers are able to quantify this reactive species in various settings, including in vitro, ex vivo and in vivo systems. This review covers a broad range of $\mathrm{H}_{2} \mathrm{O}_{2}$ sensors that have been used in biological systems, highlighting advancements that have taken place since 2015.
\end{abstract}

Keywords: hydrogen peroxide; sensors; biomedical engineering; biological applications

\section{Introduction}

Hydrogen peroxide $\left(\mathrm{H}_{2} \mathrm{O}_{2}\right)$ is a reactive oxygen species (ROS) that is present throughout the body, playing various roles in physiological processes, including cellular signaling, where it regulates cell growth, immune activation, and apoptosis [1-4]. However, at high levels, $\mathrm{H}_{2} \mathrm{O}_{2}$ can be detrimental to the body, causing cell damage [5], inflammatory disease [6], and cancer [7]. $\mathrm{H}_{2} \mathrm{O}_{2}$ 's reactivity and low physiological concentration makes accurate detection difficult, leading to confusion over the roles of $\mathrm{H}_{2} \mathrm{O}_{2}$ within the body. To improve our understanding of $\mathrm{H}_{2} \mathrm{O}_{2}$ 's role in biological systems, researchers are developing sensors to detect and quantify $\mathrm{H}_{2} \mathrm{O}_{2}$ under various conditions. This paper reviews some of the $\mathrm{H}_{2} \mathrm{O}_{2}$ sensors that have advanced the field, with a focus on advancements made since 2015 .

There are a variety of methods to detect and quantify $\mathrm{H}_{2} \mathrm{O}_{2}$ that have been in use for many years, including titration, chromotography, light detection, and electrochemical sensors [8-13]. While titration and chromotography can be used to quantify $\mathrm{H}_{2} \mathrm{O}_{2}$ levels, they are not ideal for in vitro and in vivo testing [14,15]. The two classes of sensors that are typically used for $\mathrm{H}_{2} \mathrm{O}_{2}$ detection in biological systems are light detecting sensors and electrochemical sensors [16-24]. Light detection sensors function through the detection and analysis of light emitted from a sample; besides that, they can greatly vary in their method of excitation, method in which light is changed, and emission wavelengths $[16,17]$. Chemiluminescence sensors use a chemical compound to excite or alter the $\mathrm{H}_{2} \mathrm{O}_{2}$, while fluorescence sensors use an external energy source, typically light [16,17]. Sensors frequently exhibit changes in emission intensity, but they can also function through shifts in their emission profiles, such as a red or blue shift of peaks [10,25-27].

Electrochemical sensors function through the quantification of changes in chemical energy through an electrical transducer $[18,20,23]$. Potentiometric sensors measure the potential (voltage) between probes for which there is no current $[18,20,23]$, and amperometric sensors measure the current while the potential (voltage) is maintained $[18,20,24]$. Both potentiometric and amperometric sensors have been used to quantify $\mathrm{H}_{2} \mathrm{O}_{2}$ levels and are discussed in greater detail in this paper [12,13]. 


\section{Light Detecting Sensors}

\subsection{Chemiluminescence}

Chemiluminescence (Figure 1) is a versatile detection method in which an $\mathrm{H}_{2} \mathrm{O}_{2}$ sensitive reagent promotes a chemical reaction for which the emission's signal intensity or wavelength change can be measured to determine the concentration of $\mathrm{H}_{2} \mathrm{O}_{2}$ [16]. There are many different chemiluminescence $\mathrm{H}_{2} \mathrm{O}_{2}$ sensors that could be used by researchers, including those outlined below $[10,25,28-38]$.
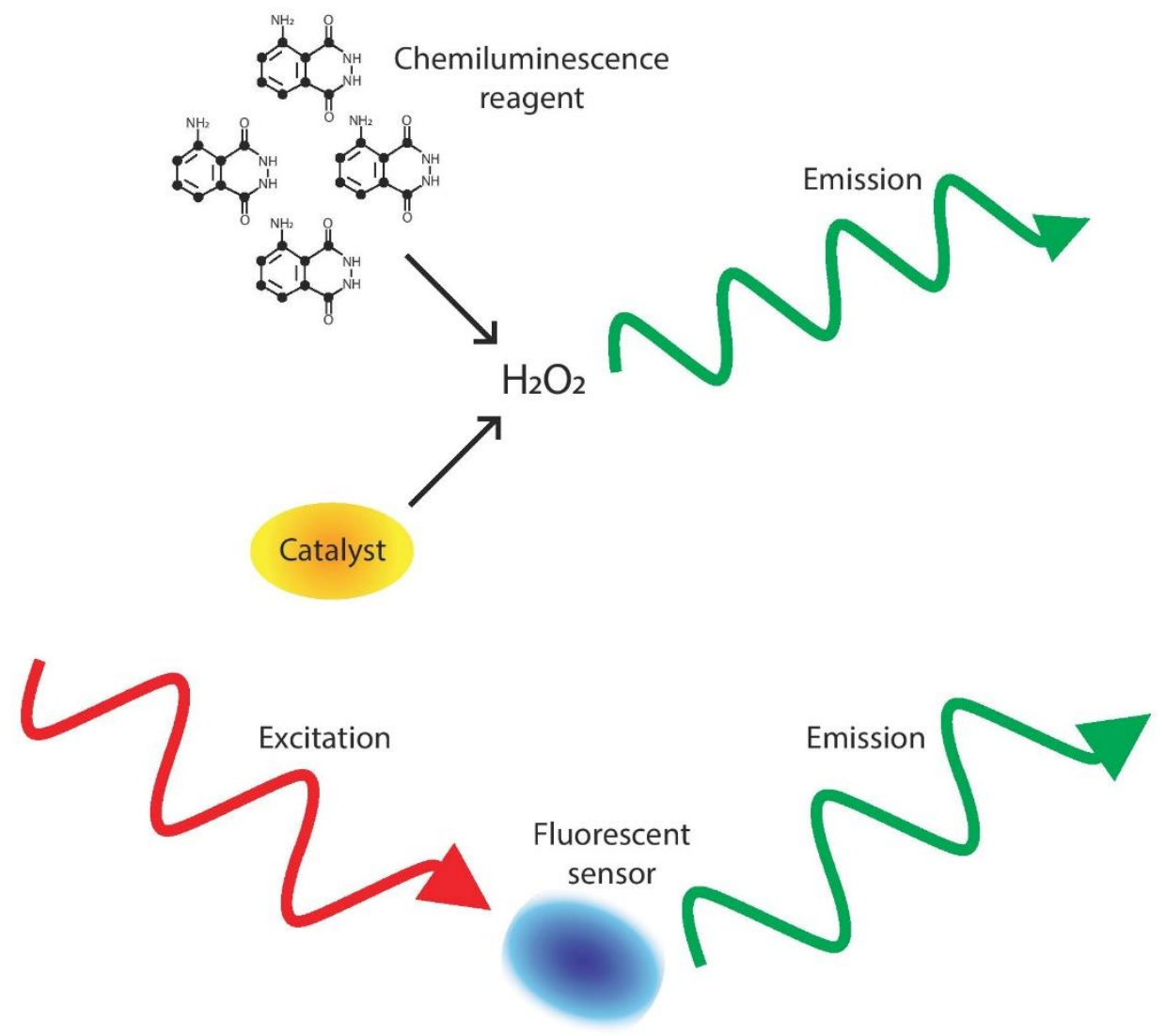

Figure 1. Process of light-based detection. In chemiluminescence detection, a substance (such as luminol) and catalyst (except in the enzyme free reactions) react with $\mathrm{H}_{2} \mathrm{O}_{2}$, causing an emission of light that can then be read to determine $\mathrm{H}_{2} \mathrm{O}_{2}$ concentration [16]. In fluorescent detection, an outside photon source excites a sample, causing an emission that corresponds to $\mathrm{H}_{2} \mathrm{O}_{2}$ concentration [17].

\subsubsection{Developments Prior to 2015}

Chemiluminescence methods include using luminol [10], eosin [28,29], peroxalate nanoparticles [25], and D-aminoluciferin [30] for $\mathrm{H}_{2} \mathrm{O}_{2}$ detection and have been used to detect $\mathrm{H}_{2} \mathrm{O}_{2}$ in the peritoneal cavity of a mouse [25], in mouse tumor xenografts [30], as an intermediate step to determine glucose levels in human serum [10], and to determine the peroxidase activity of human red blood cell membranes [29].

Of note is Lee et al.'s in vivo chemiluminescent $\mathrm{H}_{2} \mathrm{O}_{2}$ sensor created with peroxalate esters and fluorescent dyes [25]. Lee et al.'s $\mathrm{H}_{2} \mathrm{O}_{2}$ sensor can detect intramuscular exogenous $\mathrm{H}_{2} \mathrm{O}_{2}$ at a depth of $3 \mathrm{~mm}$, as well as $\mathrm{H}_{2} \mathrm{O}_{2}$ production in the peritoneal cavity during lipopolysaccharide-induced stress [25].

Reverse micelles were used to develop a luminol-based $\mathrm{H}_{2} \mathrm{O}_{2}$ sensor that allows reactions to be conducted in a low pH setting [10]. Igarashi et al. used their hexadecyltrimethylammonium bromide reverse micellar system to determine the substrate concentrations of L-phenylalanine and glucose, as well as to find the concentration of glucose in human serum [10]. 


\subsubsection{Developments from 2015 to 2019}

In 2015, Yu et al. discovered that the luminol reaction could be catalyzed by iodophenol blue, providing a less expensive method for $\mathrm{H}_{2} \mathrm{O}_{2}$ detection than the commonly used horseradish peroxidase (HRP) assays; the method also increased reproducibility compared to peroxidase-mimicking nanoparticle assays, whose detection properties depend on particle size [31].

$\mathrm{He}$ et al. used the luminol- $\mathrm{H}_{2} \mathrm{O}_{2}$ reaction to spatially position an electrochemical probe in order to record intracellular $\mathrm{H}_{2} \mathrm{O}_{2}$ levels [32]. Previously, a nanometer-sized electrode had been inserted into a cell for the electrochemical measurement of $\mathrm{H}_{2} \mathrm{O}_{2}$, but this method suffered from a lack of awareness of where the probe was located within the cell $[39,40]$. He et al. designed a chitosan-luminol probe attached to the electrochemical probe in order to provide spatial information about the probe's location within the cell, allowing for more precise data collection [32].

In 2016, Koren et al. used Prussian white's ability to convert to Prussian blue when oxidized to form a rechargeable optical sensor for $\mathrm{H}_{2} \mathrm{O}_{2}$ [33]. Prussian blue's ability to be recharged in a $0.05 \mathrm{M}$ ascorbic acid doped agarose gel allows the components to be reused multiple times [33]. Koren et al. demonstrated the ability of the Prussian white/Prussian blue assay to detect biologically-relevant samples by quantifying $\mathrm{H}_{2} \mathrm{O}_{2}$ levels in activated neutrophils [33].

In the following year, Sheng et al. used silver nanocluster-capped bovine serum albumin (BSA) as a catalyst for the luminol- $\mathrm{H}_{2} \mathrm{O}_{2}$ reaction [34]. The silver nanocluster capped BSA is a small alteration that allows for variable emission wavelengths, creating a tunable sensor [34].

Moßhammer et al. combined a previous luminescence flow injection assay technique by King et al. [38] with microdialysis probes to decrease the impact of $\mathrm{pH}$ on readings as well as to allow for the continuous monitoring of a system [35]. Moßhammer et al. demonstrated the probe's ability to detect $\mathrm{H}_{2} \mathrm{O}_{2}$ concentration in biological solutions by detecting the $\mathrm{H}_{2} \mathrm{O}_{2}$ created due to the reaction of glucose oxidase and a catalyst in a phosphate buffered saline (PBS) glucose solution. This method was used to determine the change in $\mathrm{H}_{2} \mathrm{O}_{2}$ levels in a Pseudomonas aeruginosa solution, which is known to cause acute and chronic infections in many systems throughout the body, including the urinary tract, the dermal system, and the respiratory system $[35,41,42]$.

In 2019, Wang et al. decreased the $\mathrm{H}_{2} \mathrm{O}_{2}$ detection limit of the luminol reaction via the synthesis and use of a hemin and poly(ethylene glycol) methyl ether catalyst [36]. The new catalyst resulted in a detection limit of $1.8 \mathrm{nM}$ [36], lower than other luminol- $\mathrm{H}_{2} \mathrm{O}_{2}$ detection levels [31,36,43-45].

Additionally in 2019, Jiao et al. detected intracellular $\mathrm{H}_{2} \mathrm{O}_{2}$ in cervical cancer cells (HeLa) by using iron-nitrogen-carbon single-atom nanozymes, which exhibit peroxidase-like activity, allowing for the catalyzation of $\mathrm{H}_{2} \mathrm{O}_{2}$ [37].

\subsection{Fluorescence}

Fluorescent signal detection (Figure 1), another widely used method for $\mathrm{H}_{2} \mathrm{O}_{2}$ detection, involves the quantification of a signal that is emitted from the excitation of electrons by light [17]. For fluorescence sensors, the excitation is caused by an external photon source, rather than a chemical reaction, as is the case in chemiluminescence [17].

\subsubsection{Developments Prior to 2015}

There have been several fluorescent probes using different materials made over the years, including naphthofluorescein disulfonate [46], homovanillic acid [47,48], peroxyfluor-1 [49,50], Escherichia coli OxyR [51], peroxyresorufin-1 [49], single-walled carbon nanotubes [11,52], peroxyxanthone-1 [49], and phosphine-based fluorescent reagents [53]. Fluorescent sensors have been used to detect intracellular $\mathrm{H}_{2} \mathrm{O}_{2}$ in mice peritoneal macrophages [46], to detect intracellular $\mathrm{H}_{2} \mathrm{O}_{2}$ levels when human embryotic kidney cells are bathed in $\mathrm{H}_{2} \mathrm{O}_{2}$ [49], and to measure single molecule efflux from human umbilical vein endothelial cells [11]. 
An important advancement in $\mathrm{H}_{2} \mathrm{O}_{2}$ detection occurred in 2005 with the development of three fluorescent probes from the peroxysensor family [49]. The probes are detectable via confocal and two-photon spectroscopy, and each emits at a different wavelength, allowing for different uses depending on the desired emission wavelength [49]. Miller et al. demonstrated that the probes were taken up by live human embryotic kidney (HEK) cells, where they responded to the introduction of extracellular $\mathrm{H}_{2} \mathrm{O}_{2}$; they also demonstrated that the probes can detect simulated conditions of oxidative stress in embryonic rat hippocampal neurons [49].

In 2006, Belousov et al. developed an $\mathrm{H}_{2} \mathrm{O}_{2}$ sensor named HyPer that can detect intracellular $\mathrm{H}_{2} \mathrm{O}_{2}$ levels [51]. HyPer was created from the insertion of a yellow fluorescent protein into Escherichia coli [51]. HyPer was able to detect an increase in $\mathrm{H}_{2} \mathrm{O}_{2}$ levels in HeLa cells during Apo2L/TRAIL protein-induced apoptosis and in rat adrenal medulla (PC-12) cells exposed to nerve growth factor [51].

\subsubsection{Developments from 2015 to 2019}

In 2015, $\mathrm{Xu}$ et al. developed Mito- $\mathrm{H}_{2} \mathrm{O}_{2}$, a probe specifically designed for the detection of mitochondrial-associated hydrogen peroxide [27]. After confirming the location of Mito- $\mathrm{H}_{2} \mathrm{O}_{2}$ within the mitochondria with MitoTracker Deep Red and the selectivity of the probe against several different reactive oxygen and nitrogen species, $\mathrm{Xu}$ et al. delivered Mito- $\mathrm{H}_{2} \mathrm{O}_{2}$ to HeLa cells and recorded its response to the addition of $\mathrm{H}_{2} \mathrm{O}_{2}$, confirming the creation of a mitochondrial-targeted sensor with a high selectivity and rapid response time [27].

In the following year, Xiao et al. developed two florescent probes ( $\mathrm{MI}-\mathrm{H}_{2} \mathrm{O}_{2}$ and $\left.\mathrm{ER}-\mathrm{H}_{2} \mathrm{O}_{2}\right)$ that were capable of targeting the mitochondria and the endoplasmic reticulum, respectively, have high specificity for $\mathrm{H}_{2} \mathrm{O}_{2}$, and have a fast response time [26]. $\mathrm{MI}-\mathrm{H}_{2} \mathrm{O}_{2}$ and $\mathrm{ER}-\mathrm{H}_{2} \mathrm{O}_{2}$ have different emission wavelengths and can therefore be used together to simultaneously measure $\mathrm{H}_{2} \mathrm{O}_{2}$ associated with the two organelles [26]. Xiao et al. was able to detect $\mathrm{H}_{2} \mathrm{O}_{2}$ associated with each organelle during L-buthionine sulfoximine-induced apoptosis [26].

Qian et al. developed a ratiometric $\mathrm{H}_{2} \mathrm{O}_{2}$ sensor in 2019 in an attempt to decrease the false positive and false negative readings that frequently occur with non-ratio sensors [52,54]. Using a cobalt/carbon nanotube hybrid nanocomplex as a catalyst for Amplex Red and fluorescent scopoletin, Qian et al. created a cost-effective and sensitive ratiometric $\mathrm{H}_{2} \mathrm{O}_{2}$ sensor capable of detecting hydrogen peroxide concentrations as low as $100 \mathrm{nM}$ [52].

\section{Electrochemical Probes}

Two types of electrochemical probes are frequently used for $\mathrm{H}_{2} \mathrm{O}_{2}$ detection, specifically potentiometric and amperometric [12,55]. The way in which the two classes of probes function is different. Potentiometric probes measure the potential (voltage) between a working and reference electrode in a system that has no significant current flow [18-23]. The working electrode needs to be modified so that changes in potential correlate to changes in $\mathrm{H}_{2} \mathrm{O}_{2}$ concentration, and the reference electrode must remain constant so that it can serve as a reference, or comparison, to the working electrode [18-23]. Amperometric sensors rely on the principle that changes in current are correlated to change in concentration [18-20,22,24]. Therefore, amperometric sensors use two or three electrodes to measure the change in the current of a sample while the potential (voltage) is held constant $[18-20,22,24]$.

\subsection{Potentiometric}

Potentiometric sensors (Figure 2) measure the electrical potential of an electrode when there is no significant current in the system by using a reference electrode and a functional electrode [18-23]. Electrodes are tuned to detect specific analytes with membranes that surround their surface $[20,23]$. When the target analyte reacts with the membrane, the corresponding change in electrical potential can be read by the electrode $[20,23]$. 
(A)

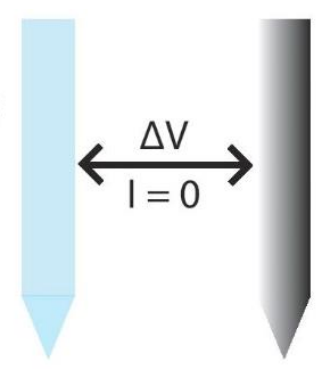

(B)

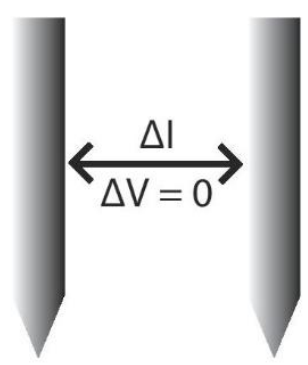

Figure 2. Two different methods of electrochemical detection. (A) Potentiometric probes measure the potential between a working and reference electrode in a system with no significant current flow [18-23]. (B) Amperometric sensors use two or three electrodes and measure the change in current while the voltage is held constant [18-20,22,24].

\subsubsection{Developments Prior to 2015}

There have been several potentiometric sensors for $\mathrm{H}_{2} \mathrm{O}_{2}$ developed over the years; unfortunately, very few have been used in biomedical systems [56]. One of the potentiometric $\mathrm{H}_{2} \mathrm{O}_{2}$ sensors to be used in biomedical research is the $\mathrm{N}, \mathrm{N}^{\prime}, \mathrm{N}, \mathrm{N}^{\prime}$-Tetramethylbenzidine with horseradish peroxidase system that has been used to detect $\mathrm{H}_{2} \mathrm{O}_{2}$ as an indicator of glucose levels in human blood samples [12].

\subsubsection{Developments from 2015 to 2019}

Parrilla et al. created a potentiometric $\mathrm{H}_{2} \mathrm{O}_{2}$ sensor in 2017 by coating platinum electrodes with Nafion, a sulfonated tetrafluoroethylene-based fluoropolymer-copolymer [57]. Parrilla et al. showed that the Nafion coating decreased signal interference from ascorbate, which commonly interferes with signal detection in biological systems, and acted as a permselective barrier, increasing the sensor's sensitivity in comparison to a bare electrode [57].

Cánovas et al. created a different Nafion-based $\mathrm{H}_{2} \mathrm{O}_{2}$ sensor in which paper coated with a Nafion membrane containing glucose oxidase was used to detect blood glucose levels [58]. The sensor is a low-cost alternative that can detect glucose levels in both human serum and whole blood samples [58].

In 2018, Iwata et al. used a previously-reported glutamate sensor, which was based on the redox reaction of a gold electrode [59], as an $\mathrm{H}_{2} \mathrm{O}_{2}$ sensor that functioned independently of the $\mathrm{pH}$ of the solution [60]. Iwata et al. showed that both a ferrocenyl methanol solution and a 11-ferrocenyl-1-undecanethiol-coated electrode were capable of $\mathrm{H}_{2} \mathrm{O}_{2}$ detection but that the ferrocenyl methanol solution had a lower detection limit [60].

\subsection{Amperometric}

Amperometric sensors (Figure 2) are similar to potentiometric sensors in that they use electrodes, but amperometric sensors use two or three [24] electrodes to measure the current at a fixed potential and therefore rely on analyte diffusion to perform their measurements [18-20,22,24].

\subsubsection{Developments Prior to 2015}

Amperometric sensors are common for $\mathrm{H}_{2} \mathrm{O}_{2}$ detection systems, and many different methods, including hemoglobin adhered to gold nanoparticle hybrid microspheres [55], graphene/platinum nanoparticles on glassy carbon electrodes [61], nanoceria capped with hexamethylene-tetra-amine or fructose [13], and (3-aminopropyl) triethoxysilane functionalized reduced graphene oxide [62] have been used in biological systems. Some of the biomedical applications for the use of amperometric sensors include quantifying $\mathrm{H}_{2} \mathrm{O}_{2}$ in disinfectants [63], determining the antioxidant activity of cerium oxide nanoparticles with rat cardiomyoblast cells (H9c2) [13], and the release of $\mathrm{H}_{2} \mathrm{O}_{2}$ from rat adrenal medulla pheochromocytoma cells (PC12) [61]. 


\subsubsection{Developments from 2015 to 2019}

Amperometric sensors have experienced a lot of improvement over the past five years, including improvements to stability [64,65], detection limit [65], and cost [66]. Since $\mathrm{H}_{2} \mathrm{O}_{2}$ can decay in rapid and unpredictable ways, Draminska et al. developed a bienzymatic system to detect the catalase reaction as well as the decay of the $\mathrm{H}_{2} \mathrm{O}_{2}$ [67]; their bienzymatic sensor is created by coating a glassy carbon electrode in multi-walled carbon nanotubes with absorbed catalase and either laccase or bilirubin oxidase [67]. Draminska et al. demonstrated the use of their sensor by measuring $\mathrm{H}_{2} \mathrm{O}_{2}$ concentration in pharmaceutical formulations [67].

Since amperometric sensors frequently rely on enzymes and mediators to facilitate electron transfer, they often suffer from instability, which can lead to inconsistent results [64,68]. A common cause of instability is enzyme dependence on $\mathrm{pH}$ [64]. Thenmozhi et al. created a more stable $\mathrm{H}_{2} \mathrm{O}_{2}$ sensor by covalently linking enzymes and mediators, specifically 3-aminopropyl trimethoxy silane with HRP and toluidine blue, which was deposited onto a graphite powder electrode [65]. Thenmozhi et al. determined that the sensor retained $86.7 \%$ of its initial response after being stored at $4{ }^{\circ} \mathrm{C}$ for three months, and they were able to use their stable sensor to quantify $\mathrm{H}_{2} \mathrm{O}_{2}$ concentrations in pharmaceutical preparations [65].

\section{Enzyme-Free Sensors}

Many amperometric sensors use enzymes, but this unfortunately leads to increased costs due to the extraction and purification techniques that are necessary to acquire the enzymes [69,70]. In 2015, Sekar et al. circumvented this extraction and purification issue by immobilizing raw turnip peroxidase and potassium hexacyanoferrate into a cellulose paper that is both disposable and biodegradable [66]. Sekar et al.'s sensor, which can be used to detect $\mathrm{H}_{2} \mathrm{O}_{2}$ in a commercial wound disinfectant, does use an enzyme, but is able to do so in a more cost-effective manner [66].

In 2016, Bai et al. created an enzyme-free $\mathrm{H}_{2} \mathrm{O}_{2}$ sensor with platinum nanoparticles and reduced graphene oxide-chitosan-ferrocene carboxylic acid nanohybrids [71]. Bai et al.'s sensors showed a negligible response to ascorbic and uric acid (two electroactive species that can interfere with $\mathrm{H}_{2} \mathrm{O}_{2}$ sensing), retained $80 \%$ of their initial value after 22 days, and successfully detected $\mathrm{H}_{2} \mathrm{O}_{2}$ released from adenocarcinomic human epithelial (A549) and stimulated human liver cancer cells (HepG2 and LO2) [71].

In 2017, Liu et al. used a porphyrinic iron metal-organic framework decorated with ordered mesoporous carbon to create an enzyme-free $\mathrm{H}_{2} \mathrm{O}_{2}$ sensor [72]. Liu et al.'s sensor was successfully used to observe the $\mathrm{H}_{2} \mathrm{O}_{2}$ levels in HeLa cells after exposure to CdTe quantum dots, which cause cells to produce increased levels of ROS [72-75].

Recently, in 2019, Liu et al. developed an immobilization-free $\mathrm{H}_{2} \mathrm{O}_{2}$ sensor, which can be created much faster than an immobilized sensor, by using the difference in diffusivity between single-stranded DNA and $\mathrm{CeO}_{2}$ nanoparticles [76]. Liu et al.'s sensor was used to detect both intercellular and extracellular $\mathrm{H}_{2} \mathrm{O}_{2}$ levels in stimulated human breast cancer cells (MCF-7) [76].

\section{Sensor Specifics}

Sensors and Biosensors Discussed in this Review as follows(Table 1): 
Table 1. Sensors and Biosensors Discussed in this Review.

\begin{tabular}{|c|c|c|}
\hline Probe & Detection Limit & Linear Detection Range $(\mu \mathrm{M})$ \\
\hline \multicolumn{3}{|l|}{ Chemiluminescence } \\
\hline $\begin{array}{l}\text { Luminol- } \mathrm{H}_{2} \mathrm{O}_{2} \text { catalyzed by } \\
\text { iodophenol blue [31] }\end{array}$ & $14 \mathrm{nM}$ & $0.025-10$ \\
\hline $\begin{array}{c}\text { Chitosan and luminol coated in } \\
\text { polyvinyl chloride/nitrophenyl octyl } \\
\text { ether [32] }\end{array}$ & $1 \mathrm{mM}$ & Not tested \\
\hline $\begin{array}{l}\text { Prussian blue/white rechargeable } \\
\text { optical sensor [33] }\end{array}$ & $0.4 \mu \mathrm{M}$ & $1-100$ \\
\hline $\begin{array}{c}\text { Luminol- } \mathrm{H}_{2} \mathrm{O}_{2} \text { catalyzed by bovine } \\
\text { serum albumin capped silver } \\
\text { nanoclusters [34] }\end{array}$ & $0.016 \mu \mathrm{M}$ & $0.14-100$ \\
\hline $\begin{array}{l}\text { Flow injection analysis with } \\
\text { microdialysis probes [35] }\end{array}$ & $\begin{array}{c}\text { Varies from } 0.01 \text { to } 1.5 \mu \mathrm{M} \\
\text { depending on the medium, } \\
\text { injection mode, and quantity } \\
\text { of reagent }\end{array}$ & $\begin{array}{c}\text { Varies from } 1 \text { to } 100 \text { depending on } \\
\text { the medium, injection mode, and } \\
\text { quantity of reagent }\end{array}$ \\
\hline $\begin{array}{c}\text { Luminol-H2O2 catalyzed by hemin } \\
\text { and poly(ethylene glycol) methyl } \\
\text { ether [36] }\end{array}$ & $1.8 \mathrm{nM}$ & $0.002-3$ \\
\hline $\begin{array}{c}\text { Iron-nitrogen-carbon single-atom } \\
\text { nanozymes [37] }\end{array}$ & $0.5 \mu \mathrm{M}$ & 500-100000 \\
\hline \multicolumn{3}{|l|}{ Fluorescence } \\
\hline $\begin{array}{l}\text { Mitochondria-targeted cationic probe } \\
\text { [27] }\end{array}$ & $0.04 \mu \mathrm{M}$ & $0.2-10$ \\
\hline Mitochondria-targeting probe [26] & $80 \mathrm{nM}$ & $0.5-15,15-40$ \\
\hline $\begin{array}{l}\text { Endoplasmic reticulum-targeting } \\
\text { probe [26] }\end{array}$ & $120 \mathrm{nM}$ & $0-40$ \\
\hline $\begin{array}{c}\text { Cobalt/carbon nanotube hybrid } \\
\text { nanocomplex [52] }\end{array}$ & $100 \mathrm{nM}$ & $0.2-20$ \\
\hline \multicolumn{3}{|l|}{ Potentiometric } \\
\hline$\overline{\text { Nafion-coated platinum electrode [57] }}$ & $3.981 \mu \mathrm{M}$ & $10-1000$ \\
\hline $\begin{array}{c}\text { Redox and enzymatic reactions with a } \\
\text { gold electrode (ferrocenyl methanol) } \\
{[60]}\end{array}$ & $10 \mu \mathrm{M}$ & $10-1000$ \\
\hline $\begin{array}{l}\text { Redox and enzymatic reactions with a } \\
\text { gold electrode } \\
\text { (11-ferrocenyl-1-undecanethiol) [60] } \\
\text { Amperometric }\end{array}$ & $100 \mu \mathrm{M}$ & $100-10000$ \\
\hline$\overline{\text { Turnip tissue, paper-based sensor [66] }}$ & $4.1 \mu \mathrm{M}$ & $20-500$ \\
\hline $\begin{array}{l}\text { Multi-walled carbon nanotube and } \\
\text { absorbed enzyme-modified electrode } \\
{[67]}\end{array}$ & $\begin{array}{c}54.4 \mu \mathrm{M} \text { (bilirubin oxidase) } \\
33.1 \mu \mathrm{M} \text { (laccase) }\end{array}$ & $\begin{array}{c}0.03-0.62 \mathrm{mM} \text { (laccase) } \\
0.05-0.99 \mathrm{mM} \text { (bilirubin oxidase) }\end{array}$ \\
\hline $\begin{array}{l}\text { Modified silane and graphite powder } \\
\text { electrode [65] }\end{array}$ & $0.171 \mu \mathrm{M}$ & $0.429-455$ \\
\hline $\begin{array}{l}\text { Platinum nanoparticles/reduced } \\
\text { graphene oxide-chitosan-ferrocene } \\
\text { carboxylic acid nano-hybrids [71] }\end{array}$ & $20 \mathrm{nM}$ & $0.02-3$ \\
\hline $\begin{array}{c}\text { Porphyrinic iron metal-organic } \\
\text { framework-decorated with ordered } \\
\text { mesoporous carbon [72] }\end{array}$ & $0.45 \mu \mathrm{M}$ & $0.5-1830.5$ \\
\hline $\begin{array}{l}\text { Single-stranded DNA and } \mathrm{CeO}_{2} \\
\text { nanoparticles [76] }\end{array}$ & $35 \mathrm{nM}$ & $0.1-1$ \\
\hline
\end{tabular}




\section{Conclusions}

Hydrogen peroxide is an important molecule within the human body, but its roles and interactions are not well understood. Before we are able to understand $\mathrm{H}_{2} \mathrm{O}_{2}$ 's role in the body, there must be reliable, fast, and versatile methods of detection with appropriate range and detection limits to function within biological systems and to detect biologically-relevant concentrations. In the past five years, researchers have continued to improve existing $\mathrm{H}_{2} \mathrm{O}_{2}$ sensors $[26,27,33,34,36,52,57,65,66,71,76]$ and developed novel methods of $\mathrm{H}_{2} \mathrm{O}_{2}$ detection $[26,27,32,66,67]$. Sensor developments have occurred in the improvement of $\mathrm{H}_{2} \mathrm{O}_{2}$ detection limits, with researchers able to detect much smaller concentrations than in the past; longevity, with researchers developing sensors that function over multiple weeks/months; and cost, with prices dropping in sensor development, this making sensors easier to manufacture at desired price points $[65,66,71]$. These improvements, and many more, have been accomplished by researchers who have expanded their materials and techniques in sensor design and manufacturing. Despite the advances that have been made in $\mathrm{H}_{2} \mathrm{O}_{2}$ detection over the past five years, there is still room for growth in the field. Between fluorescent, chemiluminescent, amperometric, and potentiometric systems, researchers have been able to detect $\mathrm{H}_{2} \mathrm{O}_{2}$ in within single cells (in vitro), solutions (ex vivo), and animal models (in vivo) [26,27,32,46,51,58,61,71]. With the continued development and refinement of $\mathrm{H}_{2} \mathrm{O}_{2}$ sensors, we predict that even more knowledge about $\mathrm{H}_{2} \mathrm{O}_{2}{ }^{\prime}$ s impact on cellular signaling and biological processes will soon be discovered.

Author Contributions: Data curation, J.M.; E.M.H.; J.A.S. and N.M.I.; writing-original draft preparation, J.M. and N.M.I.; writing-review and editing, J.M.; E.M.H.; J.A.S. and N.M.I.

Funding: This research received no external funding.

Conflicts of Interest: The authors declare no conflict of interest.

\section{References}

1. Wang, X.; Martindale, J.L.; Liu, Y.; Holbrook, N.J. The cellular response to oxidative stress: Influences of mitogen-activated protein kinase signalling pathways on cell survival. Biochem. J. 1998, 333, 291. [CrossRef] [PubMed]

2. Schreck, R.; Rieber, P.; Baeuerle, P.A. Reactive oxygen intermediates as apparently widely used messengers in the activation of the NF-kappa B transcription factor and HIV-1. EMBO J. 1991, 10, 2247-2258. [CrossRef]

3. Abe, J.; Berk, B. Fyn and JAK2 mediate ras activation by reactive oxygen species. J. Biol. Chem. 1999, 274, 21003-21010. [CrossRef] [PubMed]

4. Elias, H.; Vayssié, S. Reactive peroxo compounds generated in situ from hydrogen peroxide: Kinetics and catalytic application in oxidation processes. Peroxide Chem. 2000, 128-138. [CrossRef]

5. Imlay, J.A.; Linn, S. Mutagenesis and stress responses induced in Escherichia coli by hydrogen peroxide. J. Bacteriol. 1987, 169, 2967. [CrossRef]

6. Mittal, M.; Siddiqui, M.R.; Tran, K.; Reddy, S.P.; Malik, A.B. Reactive oxygen species in inflammation and tissue injury. Antioxid. Redox Signal. 2013, 20, 1126-1167. [CrossRef]

7. Sen, S.; Chakraborty, R.; Sridhar, C.; Reddy, Y.S.R.; De, B. Free radicals, antioxidants, Diseases and phytomedicines: Current status and Future prospect. Int. J. Pharm. Sci. Rev. Res. 2010, 3, 91-100.

8. Klassen, N.V.; Marchington, D.; McGowan, H.C.E. $\mathrm{H}_{2} \mathrm{O}_{2}$ Determination by the I3-Method and by $\mathrm{KMnO}_{4}$ Titration. Anal. Chem. 1994, 66, 2921-2925. [CrossRef]

9. Gimeno, P.; Bousquet, C.; Lassu, N.; Maggio, A.-F.; Civade, C.; Brenier, C.; Lempereur, L. High-performance liquid chromatography method for the determination of hydrogen peroxide present or released in teeth bleaching kits and hair cosmetic products. J. Pharm. Biomed. Anal. 2015, 107, 386-393. [CrossRef]

10. Igarashi, S.; Hinze, W.L. Enzymatic assay with detection by enhanced luminol chemiluminescence in a reversed micellar system: Determination of l-amino acids and glucose. Anal. Chim. Acta 1989, 225, 147-157. [CrossRef]

11. Kim, J.-H.; Patra, C.R.; Arkalgud, J.R.; Boghossian, A.A.; Zhang, J.; Han, J.-H.; Reuel, N.F.; Ahn, J.-H.; Mukhopadhyay, D.; Strano, M.S. Single-molecule detection of $\mathrm{H}_{2} \mathrm{O}_{2}$ mediating angiogenic redox signaling on fluorescent single-walled carbon nanotube array. ACS Nano 2011, 5, 7848-7857. [CrossRef] [PubMed] 
12. Wang, X.; Qin, W. Reactive intermediates-induced potential responses of a polymeric membrane electrode for ultrasensitive potentiometric biosensing. Chem. Commun. 2012, 48, 4073-4075. [CrossRef] [PubMed]

13. Ujjain, S.K.; Das, A.; Srivastava, G.; Ahuja, P.; Roy, M.; Arya, A.; Bhargava, K.; Sethy, N.; Singh, S.K.; Sharma, R.K.; et al. Nanoceria based electrochemical sensor for hydrogen peroxide detection. Biointerphases 2014, 9, 031011. [CrossRef] [PubMed]

14. Ettre, L.S.; Zlatkis, A. 75 Years of Chromatography: A Historical Dialogue; Elsevier: Amsterdam, The Netherlands, 1979.

15. Vogel, A.I.; Mendham, J. Vogel's Textbook of Quantitative Chemical Analysis; Prentice Hall: Upper Saddle River, NJ, USA, 2000.

16. Andreotti, P.E. Chemiluminescence: Principles and Applications in Biology and Medicine. J. Pharm. Sci. 1989, 78, 787. [CrossRef]

17. Guilbault, G.G. Practical Fluorescence: Theory, Methods and Techniques; M. Dekker: New York, NY, USA, 1973.

18. Galus, Z. Fundamentals of Electrochemical Analysis; Ellis Horwood: Chichester, UK; Halsted Press, a division of Wiley: New York, NY, USA, 1976.

19. Lingane, J.J. Electroanalytical Chemistry; Interscience Publishers: New York, NY, USA, 1958.

20. Pundir, C.S.; Deswal, R.; Narwal, V. Quantitative analysis of hydrogen peroxide with special emphasis on biosensors. Bioprocess Biosyst. Eng. 2018, 41, 313-329. [CrossRef] [PubMed]

21. Yunus, S.; Attout, A.; Vanlancker, G.; Bertrand, P.; Ruth, N.; Galleni, M. A method to probe electrochemically active material state in portable sensor applications. Sens. Actuators B Chem. 2011, 156, 35-42. [CrossRef]

22. Hopkins, J.; Fidanovski, K.; Lauto, A.; Mawad, D. All-organic semiconductors for electrochemical biosensors: An overview of recent progress in material design. Front. Bioeng. Biotechnol. 2019, 7, 237. [CrossRef]

23. Yunus, S.; Jonas, A.M.; Lakard, B. Potentiometric biosensors. In Encyclopedia of Biophysics; Roberts, G.C.K., Ed.; Springer: Berlin, Germany, 2013; pp. 1941-1946.

24. Villagrasa, J.P.; Colomer-Farrarons, J.; Miribel, P.L. Bioelectronics for amperometric biosensors. In State of the Art in Biosensors-General Aspects; IntechOpen: London, UK, 2013.

25. Lee, D.; Khaja, S.; Velasquez-Castano, J.C.; Dasari, M.; Sun, C.; Petros, J.; Taylor, W.R.; Murthy, N. In vivo imaging of hydrogen peroxide with chemiluminescent nanoparticles. Nat. Mater. 2007, 6, 765-769. [CrossRef]

26. Xiao, H.; Li, P.; Hu, X.; Shi, X.; Zhang, W.; Tang, B. Simultaneous fluorescence imaging of hydrogen peroxide in mitochondria and endoplasmic reticulum during apoptosis. Chem. Sci. 2016, 7, 6153-6159. [CrossRef]

27. Xu, J.; Zhang, Y.; Yu, H.; Gao, X.; Shao, S. Mitochondria-targeted fluorescent probe for imaging hydrogen peroxide in living cells. Anal. Chem. 2016, 88, 1455-1461. [CrossRef]

28. J.O'Brien, P.; Bechara, E.J.H.; R.O'Brien, C.; Duran, N.; Cilento, G. Generation of bio-electronic energy by electron transfer: Reduction of peroxidase compound I and compound II by eosine. Biochem. Biophys. Res. Commun. 1978, 81, 75-81. [CrossRef]

29. De Toledo, S.M.; Haun, M.; Bechara, E.J.H.; Durán, N. Peroxidase and hydrogen peroxide detection by a bioenergized method. Anal. Biochem. 1980, 105, 36-38. [CrossRef]

30. Wu, W.; Li, J.; Chen, L.; Ma, Z.; Zhang, W.; Liu, Z.; Cheng, Y.; Du, L.; Li, M. Bioluminescent probe for hydrogen peroxide imaging in vitro and in vivo. Anal. Chem. 2014, 86, 9800-9806. [CrossRef] [PubMed]

31. Yu, D.; Wang, P.; Zhao, Y.; Fan, A. Iodophenol blue-enhanced luminol chemiluminescence and its application to hydrogen peroxide and glucose detection. Talanta 2016, 146, 655-661. [CrossRef]

32. He, R.; Tang, H.; Jiang, D.; Chen, H.-Y. electrochemical visualization of intracellular hydrogen peroxide at single cells. Anal. Chem. 2016, 88, 2006-2009. [CrossRef]

33. Koren, K.; Jensen, P.Ø.; Kühl, M. Development of a rechargeable optical hydrogen peroxide sensor-sensor design and biological application. Analyst 2016, 141, 4332-4339. [CrossRef]

34. Sheng, Y.; Yang, H.; Wang, Y.; Han, L.; Zhao, Y.; Fan, A. Silver nanoclusters-catalyzed luminol chemiluminescence for hydrogen peroxide and uric acid detection. Talanta 2017, 166, 268-274. [CrossRef]

35. Moßhammer, M.; Schrameyer, V.; Jensen, P.Ø.; Koren, K.; Kühl, M. Extracellular hydrogen peroxide measurements using a flow injection system in combination with microdialysis probes-Potential and challenges. Free Radic. Biol. Med. 2018, 128, 111-123. [CrossRef]

36. Wang, Z.; Dong, B.; Feng, G.; Shan, H.; Huan, Y.; Fei, Q. Water soluble Hemin-mPEG-enhanced luminol chemiluminescence for sensitive detection of hydrogen peroxide and glucose. Anal. Sci. 2019, $19 \mathrm{P} 150$. [CrossRef] 
37. Jiao, L.; Xu, W.; Yan, H.; Wu, Y.; Liu, C.; Du, D.; Lin, Y.; Zhu, C. Fe-N-C single-atom nanozymes for the intracellular hydrogen peroxide detection. Anal. Chem. 2019, 91, 11994-11999. [CrossRef]

38. King, D.W.; Cooper, W.J.; Rusak, S.A.; Peake, B.M.; Kiddle, J.J.; O'Sullivan, D.W.; Melamed, M.L.; Morgan, C.R.; Theberge, S.M. Flow injection analysis of $\mathrm{H}_{2} \mathrm{O}_{2}$ in natural waters using acridinium ester chemiluminescence: Method development and optimization using a kinetic model. Anal. Chem. 2007, 79, 4169-4176. [CrossRef] [PubMed]

39. Sun, P.; Laforge, F.O.; Abeyweera, T.P.; Rotenberg, S.A.; Carpino, J.; Mirkin, M.V. Nanoelectrochemistry of mammalian cells. Proc. Natl. Acad. Sci. USA 2008, 105, 443. [CrossRef] [PubMed]

40. Wang, Y.; Noël, J.-M.; Velmurugan, J.; Nogala, W.; Mirkin, M.V.; Lu, C.; Guille Collignon, M.; Lemaître, F.; Amatore, C. Nanoelectrodes for determination of reactive oxygen and nitrogen species inside murine macrophages. Proc. Natl. Acad. Sci. USA 2012, 109, 11534. [CrossRef]

41. Yildirim, S.; Nursal, T.Z.; Tarim, A.; Torer, N.; Noyan, T.; Demiroglu, Y.Z.; Moray, G.; Haberal, M. Bacteriological profile and antibiotic resistance: Comparison of findings in a burn intensive care unit, other intensive care units, and the hospital services unit of a single center. J. Burn Care Res. 2005, 26, 488-492. [CrossRef] [PubMed]

42. Hauser, A.R.; Rello, J. Severe Infections Caused by Pseudomonas aeruginosa; Springer: Berlin, Germany, 2012; Volume 7.

43. Deng, M.; Xu, S.; Chen, F. Enhanced chemiluminescence of the luminol-hydrogen peroxide system by BSA-stabilized Au nanoclusters as a peroxidase mimic and its application. Anal. Methods 2014, 6, 3117-3123. [CrossRef]

44. Xie, J.X.; Chen, W.J.; Wu, X.X.; Wu, Y.Y.; Lin, H. Enhanced luminol chemiluminescence by Co-Fe LDH nanoplates and its application in $\mathrm{H}_{2} \mathrm{O}_{2}$ and glucose detection. Anal. Methods 2017, 9, 974-979. [CrossRef]

45. Chaichi, M.J.; Ehsani, M. Determination of glucose and cholesterol using a novel optimized luminol-CuO nanoparticles- $\mathrm{H}_{2} \mathrm{O}_{2}$ chemiluminescence method by box-behnken design. J. Fluoresc. 2015, 25, 861-870. [CrossRef]

46. Xu, K.; Tang, B.; Huang, H.; Yang, G.; Chen, Z.; Li, P.; An, L. Strong red fluorescent probes suitable for detecting hydrogen peroxide generated by mice peritoneal macrophages. Chem. Commun. 2005, 5974-5976. [CrossRef]

47. Paździoch-Czochra, M.; Wideńska, A. Spectrofluorimetric determination of hydrogen peroxide scavenging activity. Anal. Chim. Acta 2002, 452, 177-184. [CrossRef]

48. Paital, B. A modified fluorimetric method for determination of hydrogen peroxide using homovanillic acid oxidation principle. BioMed Res. Int. 2014, 2014, 8. [CrossRef]

49. Miller, E.W.; Albers, A.E.; Pralle, A.; Isacoff, E.Y.; Chang, C.J. Boronate-based fluorescent probes for imaging cellular hydrogen peroxide. J. Am. Chem. Soc. 2005, 127, 16652-16659. [CrossRef] [PubMed]

50. Chang, M.C.Y.; Pralle, A.; Isacoff, E.Y.; Chang, C.J. A selective, cell-permeable optical probe for hydrogen peroxide in living cells. J. Am. Chem. Soc. 2004, 126, 15392-15393. [CrossRef] [PubMed]

51. Belousov, V.V.; Fradkov, A.F.; Lukyanov, K.A.; Staroverov, D.B.; Shakhbazov, K.S.; Terskikh, A.V.; Lukyanov, S. Genetically encoded fluorescent indicator for intracellular hydrogen peroxide. Nat. Methods 2006, 3, 281-286. [CrossRef] [PubMed]

52. Qian, P.; Qin, Y.; Lyu, Y.; Li, Y.; Wang, L.; Wang, S.; Liu, Y. A hierarchical cobalt/carbon nanotube hybrid nanocomplex-based ratiometric fluorescent nanosensor for ultrasensitive detection of hydrogen peroxide and glucose in human serum. Anal. Bioanal. Chem. 2019, 411, 1517-1524. [CrossRef]

53. Onoda, M.; Uchiyama, T.; Mawatari, K.-I.; Kaneko, K.; Nakagomi, K. Simple and rapid determination of hydrogen peroxide using phosphine-based fluorescent reagents with sodium tungstate dihydrate. Anal. Sci. 2006, 22, 815-817. [CrossRef] [PubMed]

54. Lu, H.; Xu, S. Visualizing BPA by molecularly imprinted ratiometric fluorescence sensor based on dual emission nanoparticles. Biosens. Bioelectron. 2017, 92, 147-153. [CrossRef] [PubMed]

55. Gong, Y.; Chen, X.; Lu, Y.; Yang, W. Self-assembled dipeptide-gold nanoparticle hybrid spheres for highly sensitive amperometric hydrogen peroxide biosensors. Biosens. Bioelectron. 2015, 66, 392-398. [CrossRef]

56. Ponmozhi, J.; Frias, C.; Marques, T.; Frazão, O. Smart sensors/actuators for biomedical applications: Review. Measurement 2012, 45, 1675-1688. [CrossRef]

57. Parrilla, M.; Cánovas, R.; Andrade, F.J. Enhanced potentiometric detection of hydrogen peroxide using a platinum electrode coated with nafion. Electroanalysis 2017, 29, 223-230. [CrossRef] 
58. Cánovas, R.; Parrilla, M.; Blondeau, P.; Andrade, F.J. A novel wireless paper-based potentiometric platform for monitoring glucose in blood. Lab Chip 2017, 17, 2500-2507. [CrossRef]

59. Mizutani, S.; Okumura, Y.; Horio, T.; Iwata, T.; Okumura, K.; Takahashi, K.; Murakami, Y.; Dasai, F.; Ishida, M.; Sawada, K. Development of glutamate sensor for neurotransmitter imaging. Sens. Mater. 2017, 29, 253-260.

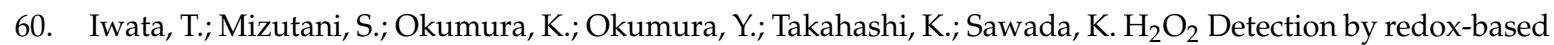
potentiometric sensors under biological environments. Sens. Mater. 2018, 30, 2359-2367. [CrossRef]

61. Zhang, Y.; Bai, X.; Wang, X.; Shiu, K.-K.; Zhu, Y.; Jiang, H. Highly sensitive graphene-pt nanocomposites amperometric biosensor and its application in living cell $\mathrm{H}_{2} \mathrm{O}_{2}$ detection. Anal. Chem. 2014, 86, 9459-9465. [CrossRef] [PubMed]

62. Guler, M.; Turkoglu, V.; Kivanc, M.R. A novel enzymatic glucose biosensor and nonenzymatic hydrogen peroxide sensor based on (3-Aminopropyl) triethoxysilane functionalized reduced graphene oxide. Electroanalysis 2017, 29, 2507-2515. [CrossRef]

63. Xu, X.X.; Zhang, J.X.; Guo, F.; Zheng, W.; Zhou, H.M.; Wang, B.L.; Zheng, Y.F.; Wang, Y.B.; Cheng, Y.; Lou, X.; et al. A novel amperometric hydrogen peroxide biosensor based on immobilized $\mathrm{Hb}$ in Pluronic P123-nanographene platelets composite. Colloids Surf. B Biointerfaces 2011, 84, 427-432. [CrossRef] [PubMed]

64. Mu, Y.; Jia, D.; He, Y.; Miao, Y.; Wu, H.-L. Nano nickel oxide modified non-enzymatic glucose sensors with enhanced sensitivity through an electrochemical process strategy at high potential. Biosens. Bioelectron. 2011, 26, 2948-2952. [CrossRef] [PubMed]

65. Thenmozhi, K.; Narayanan, S.S. Horseradish peroxidase and toluidine blue covalently immobilized leak-free sol-gel composite biosensor for hydrogen peroxide. Mater. Sci. Eng. C 2017, 70, 223-230. [CrossRef]

66. Sekar, N.C.; Ge, L.; Mousavi Shaegh, S.A.; Ng, S.H.; Tan, S.N. A mediated turnip tissue paper-based amperometric hydrogen peroxide biosensor. Sens. Actuators B Chem. 2015, 210, 336-342. [CrossRef]

67. Dramińska, S.; Bilewicz, R. Bienzymatic mediatorless sensing of total hydrogen peroxide with catalase and multi-copper enzyme co-adsorbed at carbon nanotube-modified electrodes. Sens. Actuators B Chem. 2017, 248, 493-499. [CrossRef]

68. Gibson, T.D. Biosensors: The stabilité problem. Analusis 1999, 27, 630-638. [CrossRef]

69. Oungpipat, W.; Alexander, P.W.; Southwell-Keely, P. A reagentless amperometric biosensor for hydrogen peroxide determination based on asparagus tissue and ferrocene mediation. Anal. Chim. Acta 1995, 309, 35-45. [CrossRef]

70. Campàs, M.; Carpentier, R.; Rouillon, R. Plant tissue-and photosynthesis-based biosensors. Biotechnol. Adv. 2008, 26, 370-378. [CrossRef] [PubMed]

71. Bai, Z.; Li, G.; Liang, J.; Su, J.; Zhang, Y.; Chen, H.; Huang, Y.; Sui, W.; Zhao, Y. Non-enzymatic electrochemical biosensor based on Pt NPs/RGO-CS-Fc nano-hybrids for the detection of hydrogen peroxide in living cells. Biosens. Bioelectron. 2016, 82, 185-194. [CrossRef] [PubMed]

72. Liu, J.; Bo, X.; Yang, J.; Yin, D.; Guo, L. One-step synthesis of porphyrinic iron-based metal-organic framework/ordered mesoporous carbon for electrochemical detection of hydrogen peroxide in living cells. Sens. Actuators B Chem. 2017, 248, 207-213. [CrossRef]

73. Liu, X.; Tang, M.; Zhang, T.; Hu, Y.; Zhang, S.; Kong, L.; Xue, Y. Determination of a threshold dose to reduce or eliminate CdTe-induced toxicity in L929 cells by controlling the exposure dose. PLoS ONE 2013, 8, e59359. [CrossRef]

74. Lovrić, J.; Cho, S.J.; Winnik, F.M.; Maysinger, D. Unmodified cadmium telluride quantum dots induce reactive oxygen species formation leading to multiple organelle damage and cell death. Chem. Biol. 2005, 12, 1227-1234. [CrossRef]

75. Tan, S.J.; Jana, N.R.; Gao, S.; Patra, P.K.; Ying, J.Y. Surface-ligand-dependent cellular interaction, subcellular localization, and cytotoxicity of polymer-coated quantum dots. Chem. Mater. 2010, 22, 2239-2247. [CrossRef]

76. Liu, F.; Yang, L.; Yin, X.; Liu, X.; Ge, L.; Li, F. A facile homogeneous electrochemical biosensing strategy based on displacement reaction for intracellular and extracellular hydrogen peroxide detection. Biosens. Bioelectron. 2019, 141, 111446. [CrossRef]

(C) 2019 by the authors. Licensee MDPI, Basel, Switzerland. This article is an open access article distributed under the terms and conditions of the Creative Commons Attribution (CC BY) license (http://creativecommons.org/licenses/by/4.0/). 